\title{
Limiting sediment deposition on roadways: topographic controls on vulnerable roads and cost analysis of planting grass buffer strips
}

\author{
J. Morschel ${ }^{\text {a }}$, D.M. Fox ${ }^{\text {a, }}$, J.-F. Bruno ${ }^{\text {b }}$ \\ a UMR 6012 "Espace” CNRS, University of Nice Sophia Antipolis, 98 Blvd. Ed. Herriot, P.O. Box 3209, 06204 Nice Cedex 3, France \\ ${ }^{\mathrm{b}}$ INRA/SAD, Toulouse-Auzeville, P.O. Box 27, 31326 Castanet, France
}

\begin{abstract}
Effective erosion control requires both a sound understanding of the physical context and sufficient motivation on the part of farmers to act, and in Europe this almost inevitably depends on financial subsidies. In south-west France, intense spring and summer storms lead to large scale sediment deposition on roadways, and cleanup costs are a major concern for local authorities. Current erosion control subsidy rates are not sufficient to encourage farmers to limit erosion and reduce cleanup costs. The objective of this study was to define the topographic characteristics which control sediment deposition on roadways in order to compare the cost of planting grass strips along these roads to current cleanup costs. Topographic conditions were characterised by midslope inclination (with a range of from 6 to $8 \%$ ) and distance of this slope to the road (range of 50-200 m), and these were defined by a combination of field visits, air photos, and GIS techniques. The effect of grass buffer strips on sediment deposition was estimated using the revised universal soil loss equation (RUSLE). The financial benefits of planting grass strips were based on the estimated efficiency of the buffer strips and the length of roads affected according to the topographic conditions. More than $70 \%$ of roads requiring regular cleanup occur within $200 \mathrm{~m}$ of a midlsope inclination of $6 \%$. Errors in predicting sediment deposition sites according to topography occur mainly when small scale changes in topography are beneath the resolution of the Digital Elevation Model (DEM) or when sediment deposition occurs due to the intersection of talwegs with roads. Modelling the effects of grass strips on soil erosion rates suggests that buffer strips of 12 or 24 m wide reduce sediments leaving the field by 32 and 54\%, respectively. Planting grass buffer strips along predicted problem road sections can reduce cleanup costs associated with sediment deposition. Savings in the first year of planting are in the order of about $2 \%$ of current estimated cleanup costs (100,000 $€$ ) for $12 \mathrm{~m}$ wide strips, and this amount increases to almost $35 \%$ in subsequent years for $24 \mathrm{~m}$ strips. Savings in cleanup costs can be used to increase erosion control subsidies, thereby ensuring a higher level of farmer participation. In addition to reducing sediment deposition on roadways, the grass buffer strips serve as demonstration plots for the farming community. The strategy does not directly eliminate soil degradation upslope, but it is a first step towards better erosion control.
\end{abstract}

(C) 2003 Elsevier Ltd. All rights reserved.

Keywords: Grass buffer strips; Erosion control; Sediment deposition; Erosion cleanup costs

\section{Introduction}

The physical processes of soil erosion have been the subject of intense investigation for at least half a century, but strategies to fight erosion have met with only limited success. One reason for this is that the socio-economic factors that drive erosion are rarely taken into consideration in erosion studies, so conservation planning techniques lack significance for the farmer who decides on landuse practise. Soil erosion of agricultural land in SW France has several repercussions. The main on-site consequence is long-term loss in soil productivity. Off-site, deposited sediments in ditches

\footnotetext{
* Corresponding author. Tel.: +33-4-93-37-53-80; fax: +33-4-93-37-54-30.

E-mail address: fox@unice.fr (D.M. Fox).
}

and roadways incur important costs for local public agencies. Although lost soil productivity is the greater environmental threat in the long term, it goes mostly unnoticed because of more productive crop varieties and greater fertiliser applications. Since soil degradation is not yet perceived as an important issue by farmers, soil erosion control incentives in the region have been a failure. Moreover, erosion control subsidies do not fully compensate losses in crop yields associated with measures such as grass strips or vegetated fallow. Farmers respond more to short-term financial incentives than to long-term environmental considerations (Boardman et al., 2003), so it is essential that subsidies equal per hectare revenues for farmers to adopt erosion control strategies.

Although the loss in revenues associated with soil degradation (lower yields) from erosion go largely unnoticed, short-term costs associated with road cleanups, on the other 
hand, attract attention because they generate immediate quantifiable costs. A similar situation was observed in Belgium where off-site problems focussed attention on erosion long before the risks associated with on-site degradation (Verstraeten et al., 2003). In addition, sediment deposition on roadways represents an inconvenience for commuters since roads need to be closed until cleanup operations are ended.

A short-term erosion control approach might achieve more success if efforts were concentrated on fields that repeatedly lead to large scale sediment deposition on roadways. The objective of this study is two-fold: to identify topographic controls on road deposits, and to compare the costs of applying soil erosion control measures at these sites to current cleanup costs. The use of models is an important addition to field observations in soil conservation planning (Verstraeten et al., 2003), and the revised universal soil loss equation (RUSLE) (Renard et al., 1997) was used to model the effectiveness of grass strips in order to calculate the costs of implementing erosion control strategies.

\section{Study area description}

\subsection{Environmental context}

The "Lauragais" region, where the study was conducted, is located within a larger area of crop land, the "côteaux du Sud-Ouest," near Toulouse in south-west France. It is one of France's main agricultural regions despite a hilly topography: $58 \%$ of slopes have inclinations less than 5\%; $33 \%$ have inclinations greater than 5\% and less than 10\%; and $9 \%$ have inclinations greater than $10 \%$. Slopes up to $35 \%$ are cultivated. Most slopes have a convexo-concave profile, where relatively straight segments are found between the upper convexity and lower concavity and between the lower concavity and downslope field limit. A single field generally extends from the crest down to a road or stream.

Several crop types are grown, including wheat, corn, soya beans, canola, and sunflower, but the most common crop rotation is winter wheat-sunflower. Erosion rarely occurs on wheat fields, which are well in place before spring and summer storms, but the soil is bare every second year preceding planting and growth of the sunflower crop. Towards early July, sunflower plants are sufficiently developed to protect the soil against raindrop impact and surface runoff. Therefore, the vulnerable erosion period extends from early April to early July. About $90 \%$ of roadway sediment deposits occur during this period with 52 and $38 \%$ in the spring and summer, respectively (Ministère de l'Environnement, 2000). Rainfall intensities for 2-year return periods are 71.0 and $59.2 \mathrm{~mm} \mathrm{~h}^{-1}$ for durations of 6 and $15 \mathrm{~min}$, respectively (Météo France, 2000).

Soils are formed on a calcareous substrate and belong to either calcic cambisols or calcic luvisols in the FAO taxonomy (Revel and Guiresse, 1995). Soil analyses show that typical soil textures range between 25 and $35 \%$ clay, 30 and $40 \%$ silt, and 30 and $40 \%$ sand. Aggregate stability measurements (Le Bissonnais, 1996) indicate that soil aggregate stability is good, and the soils are not particularly sensitive to surface crusting. The soil, therefore, has a relatively low inherent erodibility, but the combination of topographic and climatic factors has created erosive conditions. Water erosion is widespread, and on convex crests tillage erosion has contributed to strip the soil cover (Guiresse and Revel, 1995), so yields of sunflower and sorghum are about 20 and $30 \%$ lower, respectively, in these areas (C.A.H.G., 1994). Tillage erosion redistributes soil within the field but does not contribute to sediment deposition on roadways.

Erosion has accelerated since the 1970s due to an increase in field size. Aerial photographs of the study area show that average field size grew from 3.5 ha in 1948 to 13.4 ha in 1972 and 25.4 ha in 1998 . Fields, previously divided into different crop types, are now bare from crest to roadway; runoff velocity increases on longer slopes, as does the potential for creating zones of runoff concentration and rill erosion. In addition, natural barriers to runoff, such as hedges and wooded slopes, have been suppressed. Under certain topographic conditions, some fields generate sediment deposits on roadways. The first objective of this study is to define these topographic conditions in order to better identify and map critical areas for erosion control measures and to define slope profiles to be used in simulating the effects of grass strips.

\subsection{Erosion control and road cleanups}

Soil erosion measures are effective only if farmers are convinced they will require little investment in either time or money. Efficient use of public funds must therefore take into account the motivational impact on farmers and the public benefits gained from erosion control measures. One approach is to weigh the cost of current road cleanups against erosion control measures in high risk zones. Currently, subsidies for erosion control measures are available to farmers, and the primary objective is to protect waterways from sediment/pesticide/fertilizer inputs. This approach, however, has failed for the reasons described above (insufficient motivation due to low funding and the perception of farmers that erosion was not a critical problem) and noted elsewhere (Verstraeten et al., 2003). An alternative initial strategy would be to focus on critical road sections: one benefit of this would be to provide demonstration plots necessary to convince farmers of the efficiency of soil conservation practises (Verstraeten et al., 2003). It must be recognized that this does not address the crucial issue of soil degradation upslope, but it does initiate soil conservation practises that could later be expanded once farmer acceptance is gained.

The "côteaux du Sud-Ouest" region is divided into different administrative sectors, each with its own technical crew (Direction Départementale de l'Equipement, DDE) responsible for road maintenance. Formal records are not 
kept concerning cleanups, so it is difficult to associate particular rainfall events with deposition occurrences. In addition, some road sections require interventions two or three times per year while others only once every couple of years. Defining the topographical characteristics of vulnerable road sections facilitates both the mapping of these zones and an estimate of costs associated with applying erosion control measures to these sections.

\section{Defining vulnerable road sections}

Defining topographical characteristics and mapping high risk road sections was carried out in three steps: initial survey, definition of topographic conditions, and evaluation of the chosen conditions to represent sensitive road segments.

\subsection{Initial survey}

Highly sensitive road sections were identified with officials from the Villefranche de Lauragais office of the DDE. The sector covers an area of about $190 \mathrm{~km}^{2}$. Approximately $21 \mathrm{~km}$ of roadway were identified as requiring regular intervention, though frequency of intervention was impossible to determine since precise records were not kept. Field visits were made to each of the sites to get an initial estimate of topographic features which could contribute to sediment deposition: these included slope inclination, distance between steep slope section and roadway, and the presence of local depressions or zones of flow concentration. These visits were complemented by analyses of aerial photographs for the entire sector.

The initial survey suggested that two types of topographic controls influence sediment deposition: (1) flow is concentrated along slopes toward a thalweg, or (2) sensitive linear road sections are found along areas with steep slopes in proximity of the roadway. In the first case, sediment deposition occurs over a limited road length distance which corresponds to the intersection between roadway and thalweg. This situation accounts for only a small percentage (fewer than $10 \%$ ) of high risk road sections due to a general NW-SE crest/valley alignment of convexo-concave slopes throughout the landscape. Major roads tend to follow the crests or valleys, with valleys being affected in the valley bottoms. The second type generates longer deposition zones (up to about $1 \mathrm{~km}$ ) along roadways parallel to slope crests. For this second type, two topographic controls had to be defined: minimum critical midslope inclination and critical midslope inclination distance from the roadway.

Before going further, it is worth noting that the two topographic conditions, minimum critical slope and distance from the road, account for different physical processes. Minimum critical slope refers to the inclination of the midslope section where rill development is most extensive. Upslope sections, degraded more particularly by tillage erosion, have lower infiltration rates than downslope sections due to a combination of thinner soils and lower clay and organic matter contents (Bruno and Fox, 2003), so they generate high runoff rates. Rills develop mainly in tractor wheel depressions on midslope segments, and they frequently attain widths of about $20 \mathrm{~cm}$ and depths of $10 \mathrm{~cm}$. Midslope sections generate most of the sediments deposited on roadways, and the minimum critical slope angle referred to applies to this section. The importance of slope angle for erosion processes is well known (Renard et al., 1994; Fox and Bryan, 1999) and requires no further explanation. Slope length is a secondary topographic control increasing erosion (Renard et al., 1994), but our initial survey indicated that it shows no systematic relationship with sensitive road sections. However, in other areas this may not be the case.

The downslope section serves as the main deposition area for sediments eroded on the midslope. The second parameter, distance between minimum critical slope and roadway, refers to the length of this lower slope section. Combining downslope section inclination with distance would probably have improved the model since slope influences flow velocity (Fox and Bryan, 1999) and hence deposition rate. However, the Digital Elevation Model (DEM) does not detect subtle changes in slope required for deposition modelling. Furthermore, downslope sections have been the site of sediment accumulation over several decades (Revel and Guiresse, 1995), and they generally slope uniformly toward the ditch/roadway at an angle of about 2-3\%. Distance from the roadway therefore represents a measure of the likelihood of sediment deposition within the field and not an erosion-increasing factor as it would on the midslope section. As distance increases, deposition within the field becomes more likely.

\subsection{Defining the topographic conditions}

After the initial field and air photo surveys, several combinations of minimum critical slope inclination and distance from the roadway were tested. These included all combinations of lower slope limits of 6, 7, 8, 9 and $10 \%$ and slope distances of $50,75,100,125,150,175$ and $200 \mathrm{~m}$ (35 possibilities in all). The combination of lowest slope and greatest distance represents the least restrictive conditions, and that of steepest slope and shortest distance the most restrictive.

Model elaboration was carried out using GIS software. Layers used were the following: (1) a Digital Elevation Model (DEM) at a $50 \mathrm{~m}$ grid, (2) roadways digitised from 1:25,000 topographic maps, (3) thalwegs and river sections derived from the DEM and complimented by the addition of the historic "Canal de Midi," and (4) forested zones, obtained from 1998 aerial photographs (there is virtually no permanent grass and practically all of the area is used for crops, forests accounting for less than $5 \%$ of the surface cover).

The database was then queried to identify all road sections at the base of slopes corresponding to each of the combinations identified above: for example, all road sections within 
$200 \mathrm{~m}$ of a slope greater or equal to $6 \%$. Query results were then compared with actual road sections identified with the help of the DDE. The comparison revealed that three road section types were generated: sections with a history of cleanups predicted accurately by the slope-length combination, road sections with cleanups not identified, road sections predicted as vulnerable sites but with no record of cleanups. These sections will be considered individually in the results.

\section{Results and discussion}

\subsection{Slope-length combination results}

The distribution of road lengths according to type for all combinations are presented in Table 1. Values for total road length range from $5.9 \mathrm{~km}$ for the most restrictive conditions $(10 \%, 50 \mathrm{~m})$ to $46.4 \mathrm{~km}$ for the least restrictive $(6 \%, 200 \mathrm{~m})$. As slope diminishes (less restrictive) and as distance increases (less restrictive), total roadway length predicted by

Table 1

Road lengths $(\mathrm{km})$ for each combination of minimum midslope inclination $(\%)$ and distance $(\mathrm{m})$ of this slope from road section

\begin{tabular}{|c|c|c|c|c|}
\hline $\begin{array}{l}\text { Slope-length } \\
\text { combination }\end{array}$ & $\begin{array}{l}\text { Total road } \\
\text { length }\end{array}$ & $\begin{array}{l}\text { Correct road } \\
\text { length }\end{array}$ & $\begin{array}{l}\text { False road } \\
\text { length }\end{array}$ & $\begin{array}{l}\text { Unpredicted } \\
\text { road length }\end{array}$ \\
\hline $6-50$ & 9.7 & 3.2 & 6.5 & 19.5 \\
\hline $6-75$ & 24.8 & 7.4 & 17.5 & 15.3 \\
\hline $6-100$ & 29.5 & 9.5 & 20.0 & 13.2 \\
\hline $6-125$ & 34.5 & 11.3 & 23.2 & 11.4 \\
\hline $6-150$ & 39.6 & 13.5 & 26.1 & 9.2 \\
\hline $6-175$ & 41.7 & 14.6 & 27.1 & 8.1 \\
\hline $6-200$ & 46.5 & 16.2 & 30.2 & 6.4 \\
\hline $7-50$ & 7.8 & 2.4 & 5.4 & 20.3 \\
\hline $7-75$ & 19.7 & 6.0 & 13.7 & 16.7 \\
\hline $7-100$ & 23.8 & 7.1 & 16.7 & 15.5 \\
\hline $7-125$ & 29.1 & 9.1 & 20.0 & 13.6 \\
\hline $7-150$ & 34.3 & 11.5 & 22.8 & 11.2 \\
\hline $7-175$ & 37.3 & 12.5 & 24.8 & 10.1 \\
\hline $7-200$ & 42.7 & 14.9 & 27.8 & 7.7 \\
\hline $8-50$ & 12.1 & 3.4 & 8.7 & 19.3 \\
\hline $8-75$ & 14.4 & 4.2 & 10.2 & 18.5 \\
\hline $8-100$ & 18.3 & 5.8 & 12.5 & 16.8 \\
\hline $8-125$ & 21.9 & 7.2 & 14.7 & 15.4 \\
\hline $8-150$ & 26.8 & 9.4 & 17.3 & 13.2 \\
\hline $8-175$ & 29.5 & 10.2 & 19.3 & 12.5 \\
\hline $8-200$ & 35.6 & 13.0 & 22.7 & 9.7 \\
\hline $9-50$ & 9.8 & 3.0 & 6.8 & 19.7 \\
\hline $9-75$ & 11.8 & 3.8 & 8.0 & 18.9 \\
\hline $9-100$ & 14.1 & 4.9 & 9.2 & 17.8 \\
\hline $9-125$ & 17.3 & 6.4 & 10.9 & 16.3 \\
\hline $9-150$ & 21.2 & 8.2 & 12.9 & 14.4 \\
\hline $9-175$ & 23.1 & 8.8 & 14.3 & 13.9 \\
\hline 9-200 & 28.3 & 10.7 & 17.6 & 12.0 \\
\hline $10-50$ & 5.9 & 2.3 & 3.6 & 20.4 \\
\hline $10-75$ & 8.1 & 3.3 & 4.8 & 19.4 \\
\hline $10-100$ & 10.3 & 4.2 & 6.0 & 18.4 \\
\hline $10-125$ & 12.3 & 5.5 & 6.8 & 17.2 \\
\hline $10-150$ & 15.6 & 7.2 & 8.3 & 15.4 \\
\hline $10-175$ & 17.5 & 8.0 & 9.5 & 14.7 \\
\hline $10-200$ & 21.5 & 9.5 & 12.0 & 13.2 \\
\hline
\end{tabular}

the slope-length combination increases. The actual value of about $22.7 \mathrm{~km}$ lies between the two extremes of 5.9 and $46.4 \mathrm{~km}$, suggesting that the most restrictive conditions generate too few road segments and the least restrictive too many. Planting grass strips along the entire length would therefore generate unnecessary costs since long segments of low risk roads would be treated along with the actual problem sections. It is therefore necessary to select slope-length conditions which optimise the grass strip locations.

Three trends can be noted in Table 1. Firstly, the length of correctly predicted road segments increases with total roadway length predicted: values range from 2.3 to $16.2 \mathrm{~km}$ for the two extreme combinations cited above. Secondly, the length of unpredicted road sections diminishes as the length of correctly (or total) predicted ones increases. Thirdly, as the length of total predicted road sections increases, so does the length of falsely predicted road segments (roads with no history of cleanups). Hence, using less restrictive topographic conditions correctly predicts a larger proportion of real high risk sites, but it also classifies as high risk more road segments with no history of cleanups. The ideal slope-length combination should therefore maximise correct prediction of high risk road sections and minimise both unpredicted and falsely predicted road lengths. The selection of suitable slope-length combinations for erosion control from the list in Table 1 was carried out in two steps. In the first, it was arbitrarily decided that the combination should accurately identify at least half $(11.3 \mathrm{~km})$ the actual high risk roads. In the second, the selection was based on predicted cleanup cost savings associated with each of the retained combinations.

As mentioned above, the length of falsely predicted erosion sites increases with the length of correctly predicted sites since less restrictive conditions (lower slope-greater length) include longer segments of road. Grass strips would only diminish the costs of road cleanups on the high risk road sections; unpredicted erosion sites represent a loss in potential savings since these real high risk roads would go untreated, and falsely predicted sites would generate unnecessary expenses since their treatment would not result in a reduction in the cost of road cleanups. The two problematic situations in our analysis (unpredicted and falsely predicted sites) will be looked at in more detail before proceeding to an estimate of the actual savings from using the method to predict grass strip location from topographic conditions.

\subsection{Evaluation of the unpredicted and falsely predicted erosion sites}

Two types of roadway sections need to be looked at in more detail: these are the unpredicted erosion sites and the falsely predicted sections. Three reasons can account for unpredicted erosion sites. Firstly, some road sections occur in topographic depressions that correspond to thalwegs intersecting with roadways as described above. Slopes in proximity are less than the critical slope selected, but the concentration of flow in the micro-catchment is sufficient to 
entrain sediments onto the roadway. Secondly, local small scale changes in downslope inclination may significantly alter flow direction, and these would not be accounted for by the slope-length combination. Thirdly, limits of cleanup sections could not always be defined exactly, and since many of the unpredicted sites are next to correctly predicted zones, these may result from either small scale topographic controls or incorrectly defined road cleanup boundaries.

Many falsely predicted sections are found along tributaries of the main NW-SE drainage basin. In these sections, large amounts of sediments from adjoining fields probably enter ditches, but the slope of the ditch is sufficiently great to enable the runoff to carry sediments down to the waterway or to high risk road sections nearer the main channel. This appears to be the case for at least two of the unpredicted sites: they occur where a northward flowing ditch crosses the main NW-SE road.

\subsection{Economic considerations}

As noted by Verstraeten et al. (2003), the "implementation of certain (soil conservation) practises is highly dependent on whether or not subsidies are involved." For the purposes of the study, the DDE estimates cleanup costs at about $6.1 € \mathrm{~m}^{-3}$ of soil removed from ditches and roadways. Although no records are kept of the number of truckloads of sediment removed during a ditch/road cleanup, costs for an individual storm in June 2000, were estimated by the DDE at 30,500 $€$ for the entire sector (an additional $53,500 €$ were required for ditch bank collapse along field edges), suggesting that $100,000 €$ is a conservative annual estimate for the study area. Furthermore, if mean slope length perpendicular to sensitive road sections is estimated at about $300 \mathrm{~m}$, the erosion rate for the fields concerned is about $30-35 \mathrm{tha}^{-1}$ per year (based on an annual cost of $100,000 €, 6.1 € \mathrm{~m}^{-3}$, and a bulk density of about $1.3 \mathrm{t} \mathrm{m}^{-3}$ ), a conservative realistic estimate for the region.

Current erosion control subsidies in the region are of two kinds (Lebrun, 2000). One subsidises the planting of grass strips, the other of hedges. Both these measures are associated with other concerns, most notably nitrate pollution and biodiversity. For grass strips, the subsidy is $380 € \mathrm{ha}^{-1}$ per year (or $456 € \mathrm{~km}^{-1}$ for a $12 \mathrm{~m}$ grass strip and $912 € \mathrm{~km}^{-1}$ for a $24 \mathrm{~m}$ strip). Crop revenues in the region are about twice that amount, and are estimated at about $700 € \mathrm{ha}^{-1}$ per year; the difference in revenue explains the low farmer participation. Plants for the hedge are fully subsidised by a local government agency but planting is at the expense of the farmer, total cost for implementing this measure (plant and planting costs) is about $6 € \mathrm{~m}^{-1}$ of hedge.

The beneficial effects of grass strips in filtering nutrients, pesticides, and sediments from runoff has been proven (Hayes et al., 1984; Vought et al., 1995; Emama Ligdi and Morgan, 1995; Desta Tadesse and Morgan, 1996; Munoz-Carpena et al., 1999; Deletic, 2001). Reduction rates vary from about 50 to $95 \%$ depending on vegetation type, strip width, upslope inclination and area, and rainfall characteristics. Initial results from a current experimental trial in the study area on one of the high risk road sections suggest that a $12 \mathrm{~m}$ wide strip combined with a hedge along the field edge might be enough to entirely eliminate sediment deposits on the roadway. However, the trial has only just begun and more time is needed to confirm this result.

Since no data were available on the impact of grass strips under local conditions, the RUSLE model (Renard et al., 1994; Renard et al., 1997) was used to simulate different grass filter strip widths and slope angle combinations using data for the local climate, soil, and agricultural context. Rainfall erosivity was estimated based on a 30-year monthly rainfall record (Renard and Freimund, 1994). Soil erodibility was calculated using soil texture and organic matter data. The management index (crop type and agricultural tool sequence) was calculated by adapting the default "corn" file provided to local planting and growth rate dates and to cultivation sequences (Renard et al., 1997). The "dense grass" default file was used to simulate the grass strip. A standard convexo-concave topographical profile was used where the straight midslope section inclination was fixed at $10 \%$. Since the DEM probably underestimated slope slightly in the topographic controls on roadway deposition, and since the slope in the slope-length combinations retained refers to the minimum slope, a 10\% slope was considered more representative of actual slope conditions than the minimum. Simulations were run for 20 and $30 \%$ slopes and the proportion of sediments retained by the filter strips increased with increasing slope. Midslope distance from the road and downslope section inclination were kept at $150 \mathrm{~m}$ and $2 \%$, respectively, for all simulations. Altering the downslope length between 125 and $200 \mathrm{~m}$ had no effect on the proportion of sediments trapped for the $10 \%$ slope.

The objective of the simulations was to estimate soil loss reduction for 12 and $24 \mathrm{~m}$ width grass strips: these widths were chosen to correspond with the common $12 \mathrm{~m}$ seed planter width ( $12 \mathrm{~m}=1$ tractor pass, $24 \mathrm{~m}=2$ passes). All of the simulations were run with sunflower as the crop upslope of the grass strip since this is by far the most common crop generating sediment deposition problems.

The RUSLE model predicted that the grass buffer strips trapped 32 and $54 \%$ of eroded sediments for the 12 and $24 \mathrm{~m}$ strips, respectively, for an erosion rate of $28 \mathrm{tha}^{-1}$ on the $10 \%$ midslope section. Although few field measurements of erosion have been made (test plots have never been set up in the area), erosion rates appear realistic based on rill erosion measurements carried out on a half dozen fields in 1997 and 1998 (Bruno and Fox, 2003). The grass filter efficiency (percentage of eroded sediments maintained within the field) appears to be relatively low compared to values cited in the literature (cited above), but direct comparisons are impossible due to the different experimental conditions. This, however, suggests that actual benefits from planting grass strips might be greater than anticipated based on the results presented here. 
Table 2

Costs and savings associated with planting grass strips on the entire predicted road length: summary for the first year of planting

\begin{tabular}{|c|c|c|c|c|c|c|}
\hline \multirow[t]{3}{*}{ Slope $(\%)$-length (m) } & \multicolumn{6}{|c|}{ Grass strip (m) } \\
\hline & \multicolumn{3}{|l|}{12} & \multicolumn{3}{|l|}{24} \\
\hline & $\begin{array}{l}\text { Planting cost } \\
(€)\end{array}$ & $\begin{array}{l}\text { Reduction in cleanup } \\
\text { costs }(€)\end{array}$ & $\begin{array}{l}\text { Net savings } \\
(€)\end{array}$ & $\begin{array}{l}\text { Planting cost } \\
(€)\end{array}$ & $\begin{array}{l}\text { Reduction in cleanup } \\
\text { costs }(€)\end{array}$ & $\begin{array}{l}\text { Net savings } \\
(€)\end{array}$ \\
\hline $6-125$ & 15732 & 15930 & 198 & 31464 & 26881 & -4583 \\
\hline $6-150$ & 18058 & 19031 & 973 & 36115 & 32115 & -4001 \\
\hline $6-175$ & 19015 & 20581 & 1566 & 38030 & 34731 & -3299 \\
\hline $6-200$ & 21158 & 22837 & 1679 & 42317 & 38537 & -3779 \\
\hline $7-150$ & 15641 & 16211 & 571 & 31282 & 27357 & -3925 \\
\hline $7-175$ & 17009 & 17621 & 612 & 34018 & 29736 & -4282 \\
\hline $7-200$ & 19471 & 21004 & 1533 & 38942 & 35445 & -3497 \\
\hline $8-200$ & 16234 & 18326 & 2092 & 32467 & 30925 & -1542 \\
\hline
\end{tabular}

Costs were estimated for two time periods: the initial year of planting, and the upkeep of the grass strip during subsequent years. Cost of planting for the initial year was based on planting grass strips on the entire road length predicted by the slope-length combination (including falsely predicted segments); upkeep for subsequent years is estimated at $10 \%$ of the initial planting costs (for farmers with livestock, the grass strip becomes a source of forage in subsequent years and may actually represent a source of savings). The savings in cleanup costs were based on a $32 \%$ reduction in soil loss for the $12 \mathrm{~m}$ grass strip and $54 \%$ reduction for the $24 \mathrm{~m}$ strip, as predicted by the RUSLE simulations. The reduction in cleanup costs were then calculated for the correctly predicted road segments only.

The results of the calculations are summarized in Table 2 for the initial year and Table 3 for subsequent years. It should be noted that all the estimates lean toward the conservative side, so actual savings would probably be greater than the values cited here. For the first year (Table 2), the cost of planting $12 \mathrm{~m}$ grass buffer strips along the entire length of the predicted road sections is slightly less than the current cleanup costs, estimated at about $100,000 €$ per year. The $8 \%-200 \mathrm{~m}$ combination has the greatest savings $(2092 €)$. For the $24 \mathrm{~m}$ grass strips, the cost of planting the strips is actually greater than the cost of cleaning the roadways, and losses range from 1542 to $4583 €$.

After the first year, planting costs are eliminated and only buffer strip upkeep needs to be taken into account. The values in Table 3 show that savings in subsequent years are substantially greater than the first year. In this case, it is the 6\%-200 $\mathrm{m}$ combination that provides the greatest savings for both the 12 and $24 \mathrm{~m}$ grass strips. The most cost-effective combination in the first year is the one that minimizes the expense of planting grass strips on falsely predicted roads. Afterwards, the best combination is the one that maximizes correctly predicted road sections.

Although the savings do not fully compensate farmer revenues, they can contribute to make the buffer strips more attractive. In addition, if only the affected roadways were planted with a grass strip, the savings would compensate entirely the loss in revenues to the farmers and would be sufficient to pay for the entire subsidy. The predicted values in Tables 2 and 3 therefore represent worse-case scenarios and actual savings would probably be substantially greater as a function of both soil retention by the buffer strips and a more strategic use of grass strips.

Adding a hedge to the grass strips would cost about $126,000 €$ for the hedge alone, which is greater than the current estimated cleanup cost of $100,000 €$. The beneficial

Table 3

Costs and savings associated with planting grass strips on the entire predicted road length: summary for subsequent years

\begin{tabular}{|c|c|c|c|c|c|c|}
\hline \multirow[t]{3}{*}{ Slope $(\%)$-length $(\mathrm{m})$} & \multicolumn{6}{|c|}{ Grass strip (m) } \\
\hline & \multicolumn{3}{|l|}{12} & \multicolumn{3}{|l|}{24} \\
\hline & $\begin{array}{l}\text { Upkeep } \\
\text { cost }(€)\end{array}$ & $\begin{array}{l}\text { Reduction in cleanup } \\
\text { costs }(€)\end{array}$ & $\begin{array}{l}\text { Net savings } \\
(€)\end{array}$ & $\begin{array}{l}\text { Upkeep cost } \\
(€)\end{array}$ & $\begin{array}{l}\text { Reduction in cleanup } \\
\text { costs }(€)\end{array}$ & $\begin{array}{l}\text { Net savings } \\
(€)\end{array}$ \\
\hline $6-125$ & 1573 & 15930 & 14356 & 3146 & 26881 & 23735 \\
\hline $6-150$ & 1806 & 19031 & 17225 & 3612 & 32115 & 28503 \\
\hline $6-175$ & 1902 & 20581 & 18680 & 3803 & 34731 & 30928 \\
\hline $6-200$ & 2116 & 22837 & 20721 & 4232 & 38537 & 34306 \\
\hline $7-150$ & 1564 & 16211 & 14647 & 3128 & 27357 & 24229 \\
\hline $7-175$ & 1701 & 17621 & 15920 & 3402 & 29736 & 26334 \\
\hline $7-200$ & 1947 & 21004 & 19057 & 3894 & 35445 & 31551 \\
\hline $8-200$ & 1623 & 18326 & 16703 & 3247 & 30925 & 27678 \\
\hline
\end{tabular}


effects of hedges on reducing sediment delivery are practically impossible to estimate, so the high initial cost of planting justifies a more thorough study before proposing it as a conservation measure. However, in addition to trapping sediments, a hedge would probably reduce the high costs associated with ditch bank collapse not taken into account in this study.

\section{Conclusions}

Erosion control strategies often fail because subsidies are insufficient to motivate farmers and because farmer erosion awareness is generally low. An alternative approach to current erosion control strategies is to concentrate initially on high risk zones which generate immediate public costs. In the study area, savings from reduced road cleanups can contribute significantly to compensate farmers for planting and maintaining grass strips along problem road sections. Although this does not prevent the more serious problem of soil degradation, it initiates erosion control strategies which can be used as demonstration plots for more general application. Grass strip efficiency was relatively low in the model results provided here and there is some hope that actual reductions are greater than the predicted values. This point needs further study, as does the specific effects and benefits of a hedge. In addition to the impact on sediment delivery, the effects on bank stabilisation and biodiversity would need to be considered.

\section{Acknowledgements}

The authors gratefully acknowledge the participation of Mr. Fernandez of the Villefranche de Lauragais DDE sector. Funding for the study was provided by France's Ministry of the Environment in the GESSOL programme.

\section{References}

Boardman, J., Poesen, J., Evans, R., 2003. Socio-economic factors in soil erosion and conservation. Environ. Sci. Policy 6, 1-6.

Bruno, J.F., Fox, D.M., 2003. L'érosion hydrique dans les côteaux du Sud-Ouest: un processus dépendant du relief, des orages de printemps et des techniques culturales. In: Ecospace. The Institut National de Recherches Agronomiques (INRA), Paris, in press.

C.A.H.G., 1994. Recherche de techniques culturales d'implantation limitant les risques d'érosion hydrique: campagne 1993-1994. Chambre d'Agriculture de la Haute Garonne, Chambre Régionale d'Agriculture Midi-Pyrénées, Toulouse.

Deletic, A., 2001. Modelling of water and sediment transport over grassed areas. J. Hydrol. 248, 168-182.
Desta Tadesse, L., Morgan, R.P.C., 1996. Contour grass strips: a laboratory simulation of their role in erosion control using live grasses. Soil Technol. 9, 83-89.

Emama Ligdi, E., Morgan, R.P.C., 1995. Contour grass strips: a laboratory simulation of their role in soil erosion control. Soil Technol. 8, 109117.

Fox, D.M., Bryan, R.B., 1999. The relationship of soil loss to slope angle for interrill erosion. Catena 38, 211-222.

Guiresse, M., Revel, J.C., 1995. Erosion due to cultivation of calcareous clay soils on hillsides in south-west France. II. Effect of ploughing down the steepest slope. Soil Tillage Res. 35, 157-166.

Hayes, J.C., Barfield, B.J., Barnhisel, R.I., 1984. Performance of grass filters under laboratory and field conditions. Trans. Am. Soc. Agric. Eng. 27, 1321-1331.

Le Bissonnais, Y., 1996. Aggregate stability and assessment of soil crustability and erodibility. I. Theory and methodology. Eur. J. Soil Sci. 47, 425-437.

Lebrun, P., 2000. Evaluation technico-économique de mesures antiérosives installées sur un versant du Lauragais. Unpublished agricultural engineering student report, Ecole Nationale Supérieure Agronomique de Toulouse, Toulouse, France, 39 pp.

Météo France, 2000. Rainfall Frequency Duration Curves for Blagnac Airport. Toulouse, France.

Ministère de l'Environnement, 2000. Les coulées de boue liées à l'érosion des terres agricoles. Ministry of the Environment, Paris.

Munoz-Carpena, R., Parsons, J.E., Gilliam, J.W., 1999. Modeling hydrology and sediment transport in vegetative filter strips. J. Hydrol. 214, 111-129.

Renard, K.G., Freimund, J.R., 1994. Using monthly precipitation data to estimate the R-factor in the revised USLE. J. Hydrol. 157, 287-306.

Renard, K.G., Laflen, J.M., Foster, G.R., McCool, D.K., 1994. The Revised Universal Soil Loss Equation. Soil Erosion Research Methods, St. Lucie Press, USA, pp. 105-126.

Renard, K.G., Foster, G.R., Weesies, G.A., McCool, D.K., Yoder, D.C., 1997. Predicting soil erosion by water: a guide to conservation planning with the revised universal soil loss equation (RUSLE). In: Agriculture Handbook, vol. 703. USDA, Washington, DC.

Revel, J.C., Guiresse, M., 1995. Erosion due to cultivation of calcareous clay soils on the hillsides of south west France. I. Effect of former farming practices. Soil Tillage Res. 35, 147-155.

Verstraeten, G., Poesen, J., Govers, G., Gillijns, K., Van Rompaey, A., Van Oost, K., 2003. Integrating science, policy and farmers to reduce soil loss and sediment delivery in Flanders, Belgium. Environ. Sci. Policy 6, 95-103.

Vought, L.B.-M., Pinay, G., Fuglsang, A., uffinoni, C., 1995. Structure and function of buffer strips from a water quality perspective in agricultural landscapes. Landscape Urban Planning 31, 323-331.

Jean Morschel is a PhD candidate in the Department of Geography of the University of Nice Sophia-Antipolis, France. His thesis research focuses on reservoir watershed management in Tunisia.

Dennis M. Fox is an associate professor in the Department of Geography of the University of Nice Sophia-Antipolis, France. His current research is mainly in the area of soil erosion control in Mediterranean vineyards.

Jean-François Bruno is a research scientist at the Institut National de Recherches Agronomiques, France. His current research focuses on the effects of conservation tillage practises on soil erodibility and erosion rates. 